\title{
Legal and Practical Aspects of Child Custody, Visitation and Maintenance: A Case Study in SNNP Regional State
}

\begin{abstract}
Although divorce disrupts the marital bond thereby terminating marital rights and obligations, each parent's obligations to the wellbeing and upbringing of children (custody, visitation rights, and maintenance) persists. This article examines the practice of courts with regard to child custody, visitation rights and obligation to supply maintenance in the Southern Nations, Nationalities and Peoples (SNNP) Regional State. The experience of various court decisions in SNNP Regional State with respect to these matters is explored. Since the laws do not have detailed provisions that regulate the various issues of child custody, visitation and child support, there is inconsistency in judicial decisions. Many decisions do not distinguish between physical and legal custody. As a result, the legal and physical custody of the child usually rest on the same person. With regard to visitation, there is variation in court decisions although the conventional arrangement seems standard visitation. In some cases, courts specify the duration and form of visitation. However, in many cases, courts do not indicate how and when visitation shall be allowed. There are cases where courts overlook the issue of visitation. There is also inconsistency in court decisions with regard to child support. These problems call for detail provisions to ensure consistency and predictability in child custody, visitation and child support decisions.
\end{abstract}

Nigussie Afesha *

\section{Key terms}

Family $\cdot$ Divorce $\cdot$ Child custody $\cdot$ Visitation $\cdot$ Maintenance

DOI http://dx.doi.org/10.4314/mlr.v11i2.2

Received: 8 August 2017 Accepted: 30 December 2017

This article is licensed under a Creative Commons Attribution-

NonCommercial-NoDerivs (CC BY-NC-ND)

\footnotetext{
* Nigussie Afesha (LLB, MA), Assistant Professor, College of Law and Governance, School of Law, Hawassa University. The author can be reached at $<$ nigussie.afesha12@gmail.com>.

I thank my colleagues Dr. Beza Dessalegn and Mr. Bisrat Mulugeta (Hawassa University, school of law) for their comments and insightful suggestions. I am also grateful to Dr. Elias N. Stebek and the anonymous reviewers for their contribution toward the improvement of the article.
} 


\section{Introduction}

Family has been understood as an essential element in human life. "It is of great legal interest because of the decisive role it has historically played in the raising and socialization of children and in mutual economic support of its members". ${ }^{2}$ In this sense, family is considered as the natural and "fundamental unit of a society". ${ }^{3}$ Marriage, one of the essential ways to form a family, is usually considered the most fundamental building block of human societies. ${ }^{4}$ Thus, the institution of marriage, found practically in all human societies, ${ }^{5}$ strives mainly to establish a stable framework in which children are cared for and supported, both emotionally and financially. ${ }^{6}$ It should be noted that the continuation of a marital relationship is an indispensable foundation to achieve such function of the institution of marriage. Such essence of institution of marriage will subsist if and only if spouses are willing to live together and the marital relation does not come to an end. A change in the status of the spouses (from married to single) may alter the rights and responsibilities of the parents over their children. Divorce is one of the legal mechanisms through which spouses can change their legal status to single, and set aside the matrimonial bonds and marital rights and obligations, except for those obligations that persist by law (for instance post-divorce upbringing of children). ${ }^{7}$ It is meant to say that "[d]ivorce is fundamentally a dispute between the husband and wife, and regardless of the reasons for their separation, the bond between parent and child remains". 8

It is understandable that a decision to divorce is a difficult one and most painful when children are involved. The split of parents has negative impact

\footnotetext{
${ }^{1}$ Bruce W. Frier and Thomas A.J. McGinn (2004), A Casebook on Roman Family Law, published by Oxford University Press, New York, p. 3.

2 Ibid.

${ }^{3}$ See article 34(3) of the FDRE and the SNNP Regional State Constitution.

${ }^{4}$ Frier and McGinn, supra note 1, p. 25.

${ }^{5}$ Shoshana Grossbard-Shechtman (2003), "Marriage and the Economy” in the Shoshana A. Grossbard-Shechtman (ed.) Marriage and the Economy: Theory and Evidence from Advanced Industrial Societies, Cambridge University Press, Cambridge, pp.1-36, p. 1.

${ }^{6}$ Barbara Stark (2005), International Family Law: An Introduction, Ashgate Publishing Company, USA, p. 14.

${ }^{7}$ Id., p. 75.

${ }^{8}$ Takao Tanase (2011), "Divorce and the Best Interest of the Child: Disputes over Visitation and the Japanese Family Courts", Pacific Rim Law \& Policy Journal, Vol., 20, No 3, pp. 563-588, p. 571.
} 
upon children's lives. ${ }^{9}$ One can mention issues of upbringing, the rights of the parents and the children to visit each other, and the duty to supply maintenance. There are major issues concerning children that must be resolved during the proceedings of divorce. ${ }^{10}$ Custody and support arrangements and concerns regarding children's well-being are given utmost attention by most parents. ${ }^{11}$ In general, parents have two options with regard to how children can be taken care of after divorce: i.e., they will either work it out by themselves or let the court decide it for them. ${ }^{12}$

When courts, upon divorce, make decisions about where children live, how much contact the other parent has and who can supply maintenance, their decisions should be based on the best interest of children. ${ }^{13}$ This means, during the divorce process, if the court finds that the custody agreement, which has been worked out by spouses, is in the child's best interest, a court will approve it. ${ }^{14}$ However, if parents fail to reach an agreement regarding the custody of the child or if their agreement is found to be against the interest of the child, the court decides the issues on its own in a way that ensures the best interest of the child. ${ }^{15}$

This limits an unwarranted claim of child custody and avoids more disruption in children's lives than the separation of their parents is already causing. The important thing here is fixing or determining which custody arrangement is best for the child. This in effect involves determining who should be a custodial parent and who has visitation right. This is because, in legal terms, when one is the custodial parent, the other is systematically becoming the noncustodial parent with visitation rights. ${ }^{16}$

The bond between a parent and child continues irrespective of the decision to divorce, ${ }^{17}$ and parents are, in effect, still obligated to undertake parental rights

${ }^{9}$ Rebecca A. DeSimone (2002), Child Custody, Visitation, and Support in

Pennsylvania, $1^{\text {st }}$ ed., Sphinx Publishing Inc, United States of America, p. 26

10 Roderic Duncan (2007), A Judge's Guide to Divorce: Uncommon Advice from the Bench, Consolidated Printers, USA, p. 175.

${ }^{11}$ Stark, supra note 6, p. 75.

12 Emily Doskow (2006), Nolo's Essential Guide to Divorce, $1^{\text {st }}$ ed., Consolidated Printers, U.S.A, p. 139.

${ }^{13}$ Patrick Parkinson (2011), Family Law and the Indissolubility of Parenthood,

Cambridge University Press, New York, p. 3.

14 Sanford N. Katz (2011), Family Law in America, Oxford University Press, New York, p. 111, and see article 113 of the Revised Family Code.

${ }^{15}$ See Art 221 of the Revised Family Code and Art 236 of the SNNP Regional State Family Code.

${ }^{16}$ Doskow, supra note 12, p. 142.

17 Tanase, supra note 8, p. 571. 
and responsibilities even in the aftermath of the dissolution of marriage. There are three key issues relating to children that must be resolved during the proceedings of divorce. These are child custody, the rights of the parents and the children to visit each other, and an obligation to supply maintenance. There are various principles that suggest which types of custody arrangements offer the best comfort zone for the child and how the post-divorce parental rights and obligations are regulated. It should be noted that the kind of child custody arrangement a court decides will ultimately influence the type of visitation right the noncustodial parent has as well as the amount of child support one parent owes to the other.

This article examines these practices of child custody, visitation right and child support award in SNNP regional state courts. The first two sections deal with conceptual and theoretical frameworks of child custody, visitation and child support award. Sections 3, 4 and 5 deal with the legal framework and they discuss the various components of child custody and visitation (which are usually considered as post-separation living arrangements of the child), and illuminate issues related to child support. Court decisions with regard to postseparation living arrangements of the child are also examined. Moreover, the types of child custody, forms and frequency of visitation as well as pattern of child support assessment are discussed.

\section{Child custody: Overview of Concepts and Overall Practices}

As a rule, parents are joint guardians of their children and have joint custody during marriage. ${ }^{18}$ By implication, a guardian has responsibility for the longterm welfare of the child and has all the powers and duties in relation to the child, including day-to-day care. ${ }^{19}$ When parents separate, there is a need to consider custody of the children, that is, who should undertake day-to-day care and control of the child, and whether a noncustodial parent should have access to the child and on what terms. ${ }^{20}$ Child custody refers to the post-separation

\footnotetext{
${ }^{18}$ Katz, supra note 14 , p. 77.

19 See, Debbie Ong Siew Ling (1999), "Parents and Custody Orders: a new approach.” Singapore Journal of Legal Studies, pp. 205-228, p. 205. She argues: "When divorce terminates a marriage, the children of the marriage lose a fundamental cornerstone to their world of happiness and security. The law recognizes the welfare of such children to be of paramount importance. The court makes custody orders which it considers to be the best for the children under the circumstances. It is proposed that the law should move towards instilling in parents a greater sense of responsibility for their children by embracing the concept that parenthood is for life and that parenthood entails heavy responsibilities.” (Emphasis, added)

${ }^{20}$ Rosemary Dalby (2001), Essential Family Law, Cavendish Essential Series, (2 ${ }^{\text {nd }}$ ed.), Cavendish Publishing, Australia, p.77.
} 
living arrangements of minor children ${ }^{21}$ that involve defining the legal and physical rights and responsibilities parents have over their children. ${ }^{22}$ In other words, child custody involves the legal authority to make decisions on the medical, educational, health, and welfare needs of a child, on the one hand, and physical control over a child, on the other. ${ }^{23}$ This shows that child custody has two components: physical and legal. ${ }^{24}$

\subsection{Legal custody}

Legal custody involves making long-term parenting decisions regarding education, medical treatments, discipline, psychological counseling and religion of the minor child. ${ }^{25}$ Custodial parents have the right to make decisions on issues like which school children should go, what religion they practice, whether they need psychological counseling, and when they shall see a doctor. ${ }^{26}$ Such roles of the parents, otherwise called legal custody, on the basis of the specific role of each or both parents, are further classified into joint custody and sole custody.

In joint legal custody parents participate in the decisions on upbringing of a child. $^{27}$ They share the responsibilities of raising their children, including decisions about education, religion, medical treatment, and residence. In joint legal custody, "neither parent has final decision-making authority without consulting the other parent." ${ }^{28}$ In this case, there is a duty placed on the custodial parent to exchange information with the noncustodial parent based on the presumption that the noncustodial parent is a partner in raising their child and should be able to communicate freely with the child, be informed of the child's school performance, and be notified immediately if the child is undergoing medical treatment or has had a medical emergency. For this reason, "joint legal custody makes more sense when the two parents can agree and find a way of working together to take care of the children". ${ }^{29}$ Children will benefit if the parents can raise them in harmony with each other whereby each parent

${ }^{21}$ Stark, supra note 6, p. 182.

${ }^{22}$ Alison Clarke-Stewart and Cornelia Brentano (2006), Divorce: Causes and Consequences, Yale University Press, New Haven and London, p. 176.

${ }^{23}$ Violet Woodhouse, (2006), Divorce and Money: How to Make the Best Financial Decisions during Divorce, $8^{\text {th }}$ eds. Consolidated Printers, USA, p. 357.

${ }^{24}$ Doskow, supra note 12, p. 140.

${ }^{25}$ James J. Gross and Michael F. Callahan (2006), Money and divorce: The First 90 Days and After, Sphinx Publisher, united states of America, p. 87

${ }^{26}$ Doskow, supra note 12, p 140.

${ }^{27}$ Gross and Callahan, supra note 25, p 87.

${ }^{28}$ Id., p. 87.

${ }^{29}$ Ibid. 
participates in the real parenting effort, and neither bears the sole burden of caring for the children. ${ }^{30}$

Unlike joint custody, in which both parents will make decisions about the child, sole legal custody allows only one parent to make decisions about the upbringing of the child. ${ }^{31}$ This means, sole legal custody grants the custodial parent the right to make all major decisions without consulting the other parent ${ }^{32}$ otherwise called 'winner-takes-all notion of custody' ${ }^{33}$ For this reason, the sole legal custodial parent exclusively decides where the kids will go to school, what religion they will have and where they will live. In various societies, such parent consents on issues of marriage and or entry into the armed services. ${ }^{34}$ In addition, sole legal custody grants exclusive physical custody to one parent. It should be noted that granting one parent both sole legal and physical custody is typically done only when the other parent has neglected or abused the child (as explained in Section 1.2 below), ${ }^{35}$ or "if there is so much hostility that parents simply cannot communicate at all, or if one parent lives at a great distance, or one parent simply is not involved in the child's day-to-day life and does not spend time with the child."36

\subsection{Physical custody}

Physical custody gives the parent rights and responsibilities for the daily care and control of the child. ${ }^{37}$ Physical custody is also referred to as 'residential custody ${ }^{38}$ It simply means a place where the children live most of the time or on a regular basis. The parent with physical custody has the cares and controls of the children on a day-to-day basis, this includes the power to make short-term parenting decisions rather than long-term ones that may go with the notion of legal custody. Physical custody can be joint/shared, sole, or split. ${ }^{39}$

Joint physical custody became an alternative disposition to sole custody, which warrants exclusive physical control to one parent and visitation to another. ${ }^{40}$ Joint physical custody grants physical custody rights to both parents. Parents who share physical custody typically also share legal custody; however,

\footnotetext{
${ }^{30}$ Ibid.

31 Ibid.

${ }^{32}$ Clarke-Stewart \& Brentano, supra note 22, p. 177.

${ }^{33}$ Parkinson, supra note 13, p. 45

${ }^{34}$ See for example, Gross and Callahan, 2006, supra note 25, p 87.

${ }^{35}$ Clarke-Stewart \& Brentano, supra note 22, p. 177.

${ }^{36}$ Doskow, supra note 12, p. 140.

${ }^{37}$ Clarke-Stewart \& Brentano, supra note 22, p. 176.

${ }^{38}$ Gross and Callahan, supra note 25, p. 87.

${ }^{39}$ Gross and Callahan, supra note 25, p. 87.

${ }^{40}$ Katz, supra note 14, p. 111.
} 
conversely, sharing legal custody does not necessarily entail shared physical custody. Joint physical custody does not necessarily mean equal (fifty-fifty) time-sharing, but it reflects that the child spends substantial time with each parent. Elaborating this point, Dalby notes, "Joint custody means both parents share parental responsibilities equally, although the time spent with the child may be divided unequally". ${ }^{41}$ Parents with joint physical custody may have a parenting plan which may be specified by a court order, or it could be an informal arrangement by the parents that specifies the actual time the child spends with each parent. ${ }^{42}$ In principle, both parents would share physical custody in law until the court orders otherwise. This is true even if they are separated and the children are actually only living with one of them. ${ }^{43}$ Courts generally prefer shared physical custody because such kind of arrangement gives children regular contact with both parents and this arrangement can substantially mitigate the emotional burden on the children, which could be created as result of divorce. ${ }^{44}$

Joint physical custody has numerous benefits. Form the side of the parents, joint physical custody alleviates the sense of loss that a noncustodial parent feels and relieves a custodial parent from some of the burdens sole care and responsibility for children would create. ${ }^{45}$ It may also lessen stress, which may be caused by changes in family structure or function. "A functioning joint custody arrangement provides parents with a better balance of time with and without children., ${ }^{46}$ In a nutshell, joint custody has been linked to higher satisfaction with the custody arrangement in parents, if the parents choose joint custody and cooperate for the same than imposed by court. ${ }^{47}$ In self-selected arrangements, joint custody translates into more involvement of parents and more positive attitudes toward the ex-spouse's parenting. ${ }^{48}$

From the perspective of children, joint physical custody has the advantage of assuring children continuing contact with both parents and gives them a greater sense of security and lessens their sense of abandonment by one parent. ${ }^{49}$ Joint custody has also been linked to lower rates of re-litigation provided that joint custody is freely chosen by parents rather than imposed by the court. ${ }^{50}$ On the

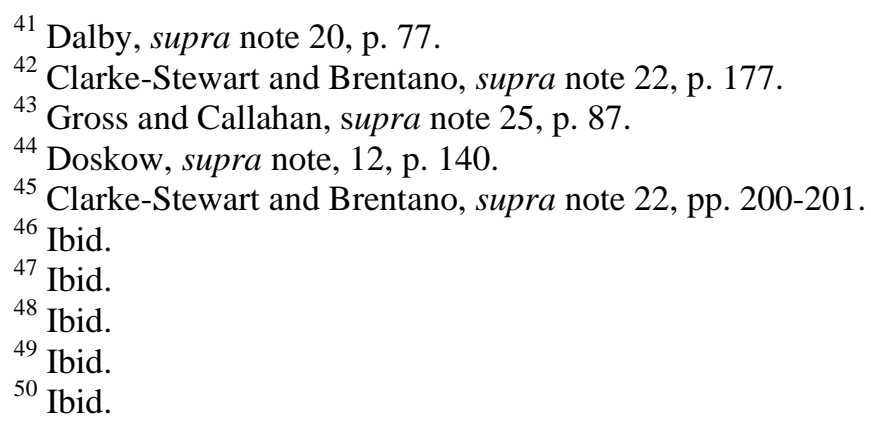


contrary, court-imposed joint custody has not been found to reduce relitigation. $^{51}$

Nevertheless, despite its multitude of advantages joint custody is not without its drawbacks. For one thing, it poses problems for a parent who wants to move to a different area. For another, even if parents stay in the same area, joint custody leads to lesser stability for children, who are shuttled between their parents, encountering differences in household rules, parental expectations, and sometimes even socioeconomic status as they move from one household to the other. ${ }^{52}$ Children who moved more frequently between their parents are often at a risk for emotional and behavioral problems, probably because frequent access creates more opportunities for disagreements between the parents. ${ }^{53}$

On the other hand, when children live primarily with one parent, it is called sole physical custody. ${ }^{54}$ If one parent has the children most of the time, that parent is usually granted sole physical custody; the other parent gets the right to regular visitation. ${ }^{55}$ The non-custodial parent may also have actual physical custody of the child for agreed periods of time. ${ }^{56}$

When siblings are split between parents, it is called split physical custody. Split custody refers to "splitting" of siblings between the parents and may entail any combination of physical and legal custody. ${ }^{57}$ Split custody is easiest to describe in a situation where there are two or more children and each parent obtains full physical custody over one child. ${ }^{58}$ However, courts believe it is usually in the best interests of the children to keep siblings together. ${ }^{59}$ Some of the considerations that may bring about this result are age of the children and child preference. ${ }^{60}$

Courts often want to know whether one custodial arrangement is best. Because of the great diversity among parents, children, and their circumstances, there is no single best solution to the custody dilemma; one cannot say that any one type of arrangement is better for all children or parents. However, courts spend many hours trying to pin down the relative advantages and disadvantages of each. They also determine the kind of physical or legal responsibilities that

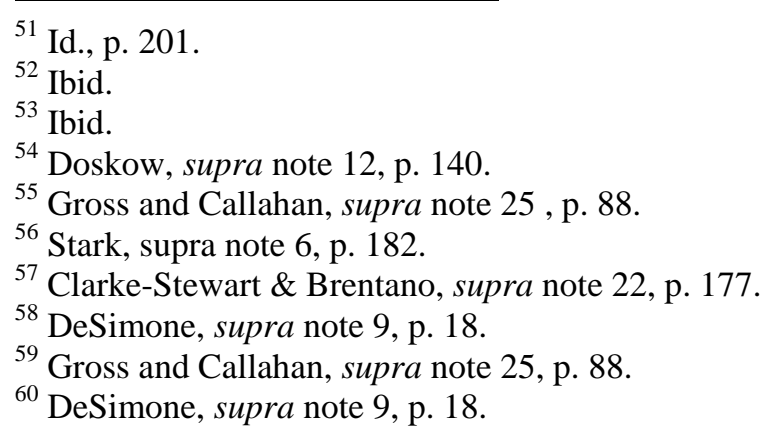


parents assume over their children and the manner in which such custody arrangement will be enforced.

There are states that determine custody by the age of the child under the premise that a divorced mother is typically entitled to custody of boys until seven years of age and girls until nine years. ${ }^{61}$ The father is generally considered the custodial of older children. In some other states, such as Algeria, a divorced wife may be granted custody of boys until the age of sixteen years and retain girls until eighteen years, as long as the mother does not remarry. ${ }^{62}$ In Egyptian family law, a father has custody of sons over the age of seven and daughters over the age of nine. ${ }^{63}$

In most western states, custody is determined according to the 'best interest of the child', and this standard encourages a detailed case-by-case analysis. ${ }^{64}$ This envisages that courts evaluate all relevant factors; inter alia, ${ }^{65}$ wishes of the parents and the child. The parents' wishes as to who receives custody will not be the lone factor of the actual award. Too often, parents seek custody for reasons other than what is best for the child. Some parents may be motivated by a desire for revenge against the other parent. ${ }^{66}$ Others may petition for custody hoping that they can bargain for a lesser child support obligation. Courts, therefore, will consider the parents' wishes, but generally will not base an award of custody on those wishes without other evidence that ensures the child's best interest. ${ }^{67}$

A court sometimes asks the child with whom s/he prefers to live. The amount of weight the court gives to the child's preference depends on the age and level of maturity of the child. ${ }^{68}$ Children under the age of eight usually will not be consulted about their choice of custodial parent. ${ }^{69}$ Courts, on the other hand, often give considerable weight to the wishes of children aged fourteen and above provided that the child's preference is on the basis of his/ her relationship with the preferred parent and not on some other factor. ${ }^{70}$

Where one parent is the custodial parent, the other non-custodial parent has visitation rights. In other words, if one parent has sole physical custody, the

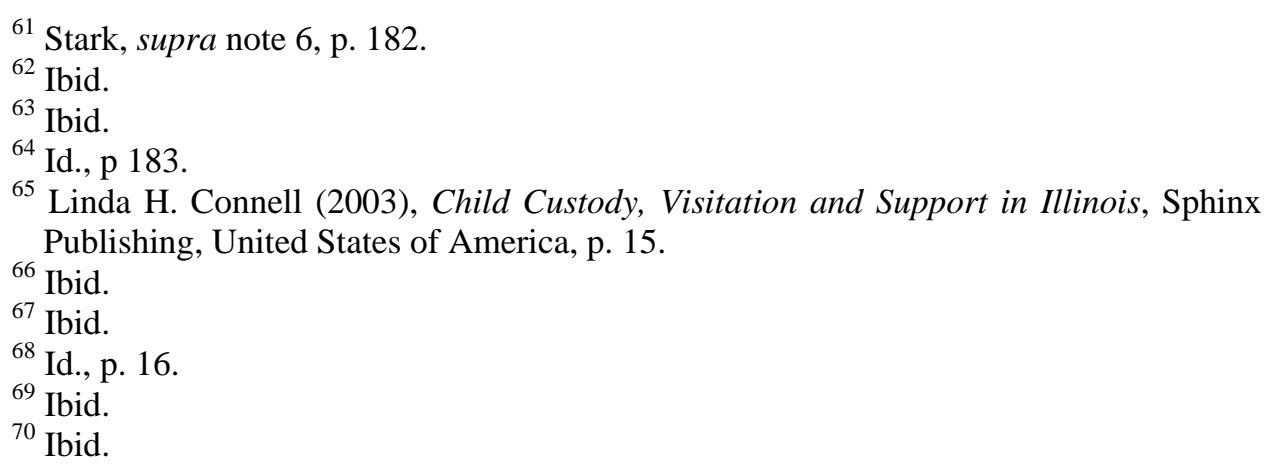


other parent will have visitation rights as agreed by the spouses or ordered by court. $^{71}$

\section{Visitation and Maintenance}

\subsection{Visitation}

The right of visitation, or access of noncustodial parents to a child, is favored in many States. ${ }^{72}$ Visitation, which could be agreed by the spouses or ordered by court, defines the conditions for the noncustodial parent to have contact with the child or provides for a child to maintain physical contact with both parents on a regular basis. ${ }^{73}$ This is because parents have a fundamental right to spend time with their child after divorce regardless of their separation or unhealthy relationships. ${ }^{74}$ When the child has established relationship with a noncustodial parent, the latter is likely to contribute much to the child's wellbeing. ${ }^{75}$ However, visitation should not conflict with the long-range decisions of the parent with legal custody. For instance, if the parent with legal custody has decided to raise the child in a certain faith, the parent with visitation rights may not be allowed to influence the child to enter into other religious conviction. ${ }^{76}$

"Although visitation is widely believed to be beneficial to children and parents, there is substantial research evidence which highlights the difficulties in establishing workable arrangements with which both spouses become happy."77 In most jurisdictions, courts ostensibly make such decisions based on the best interests of the child, ${ }^{78}$ which means the best-interest standard plays some role in visitation decisions. ${ }^{79}$ When visitation is unhealthy, it might be contrary to the best interest of a child. ${ }^{80}$ Consequently, courts are expected to determine the type, frequency and particular forms of visitation.

Visitation may be categorized into standard, supervised and virtual visitation based on the timing and the manner in which visitations will be conducted. ${ }^{81}$ In

${ }^{71}$ Doskow, supra note 12, p 142.

${ }^{72}$ Stark, supra note 6, p. 159.

73 Id., p. 161.

${ }^{74}$ James G. Dwyer (2006), The Relationship Rights of Children, Cambridge University press, New York, p. 47.

${ }^{75}$ Ibid.

${ }^{76}$ DeSimone, supra note 9, p. 51.

${ }^{77}$ Ian Butler \& other (2003), Divorcing Children: Children’s Experience of Their Parents’ Divorce, Jessica Kingsley Publishers, London, pp. 118-120.

${ }^{78}$ Dwyer, supra note 74, p. 49.

${ }^{79}$ Id., p. 47.

${ }^{80}$ Id., p. 48.

${ }^{81}$ With regard to the possibility of various kind of visitation, see, for example, Dwyer James G., The Relationship Rights of Children, supra note, 74, p. 49; DeSimone 
standard visitation, the non-custodial parent is allowed to take the child for one/two overnights every week, weekend visitation once per month and extended periods of visitation during vacations from school and over the summer or a couple of weeks in the wintertime. ${ }^{82}$ Supervised visitation, on the other hand, allows the noncustodial parent to visit a child only in the company of another person (usually a friend or a relative, whom the two parents agree to act as chairperson) or under supervision of child protective workers. ${ }^{83}$

A court may order supervised visitation especially to guard children against a perceived possibility of abuse or neglect. ${ }^{84}$ Supervised visitation often calls for a restriction of visitation to a particular location and time. ${ }^{85}$ The objective is to enable the noncustodial parent to maintain a relationship with the child while assuring the child's safety. ${ }^{86}$ Hence, supervised visitation can be ordered to ensure continuation of the parent and child relationship while maintaining the health, safety and welfare of the children.

The last form of visitation is virtual visitation which may be ordered where there is a long distance between the households of custodial and noncustodial parents. ${ }^{87}$ Virtual visitation allows the child to virtually spend time and interact with his or her noncustodial parent. "Virtual visitation is ordered to supplement traditional physical visits when the geographic distance of a move precludes frequent, in-person visitation". ${ }^{88}$ In this sense, "Virtual visitation can be used as part of a compromise solution, allowing the child to relocate with the custodial parent, while still maintaining and fostering a relationship with the noncustodial parent. Consequently, virtual visitation may make it more difficult for a noncustodial parent to prevent the custodial parent from re-locating”. ${ }^{89}$ Here, the matter is balancing the rights of the custodial parent to live far from the noncustodial parent, on the one hand, and the right of the non-custodial parent to

Rebecca A., Child Custody, Visitation, and Support in Pennsylvania , supra note, 9; Barbara Stark, International Family Law: An Introduction, supra note, 6, pp.159-160 and others.

${ }^{82}$ Dwyer, supra note 74, p. 49.

${ }^{83}$ DeSimone, supra note 9, pp. 51-52.

${ }^{84}$ Dwyer, supra note 74, p.47.

${ }^{85}$ DeSimone, supra note 9, p. 51-52.

${ }^{86}$ Stark, supra note 6, pp.159-160.

${ }^{87}$ Kimberly R. Shefts (2002), "Virtual Visitation: The Next Generation of Options for Parent-Child Communication”, Family Law Quarterly, Vol. 36, No. 2, pp. 303-327, p. 311.

88 Jenna Charlotte Spatz (2011), “Scheduled Skyping with Mom or Dad: Communicative Technology's Impact on California Family Law”, Loyola of Los Angeles

Entertainment Law Review, Vol. 31 No. 143, pp. 143-172, p. 145.

${ }^{89}$ Id., p. 144. 
remain in close physical proximity to his or her children, on the other. In such a case, the court may order the custodial parent to communicate with the noncustodial parent and their children via the internet to maintain emotional interaction between the noncustodial parents and their children. ${ }^{90}$

There is a presumption that noncustodial parents will receive one of the aforementioned types of visitations. However, in rare cases, visitation rights may be restricted if such visits would seriously endanger the child's welfare. ${ }^{91}$ Visitation is, inter alia, meant to facilitate opportunities for children to have safe and conflict-free access to both parents and maintain personal relations and direct contact with both parents on a regular basis. ${ }^{92}$ Suspension or denial of this right thus amounts to violation of the rights of children and a failure to take account of their interests. ${ }^{93}$

However, the right may be blocked if it poses a threat to a child's safety, physical or mental health or other adverse effects on the feelings and emotional stability of the child. ${ }^{94}$ Access to parent should be regarded, as a basic right of the child and it has an important contribution to the latter's emotional and material wellbeing. ${ }^{95}$ If a custodial parent restricts a noncustodial parent's access to the child without due cause, it amounts to failure to cooperate with the right of the child to his/her emotional and material development which may result in a change of custody ${ }^{96}$ Hence, denial of visitation is rare and generally requires a finding of actual harm, such as physical violence to the child, drug addiction, sexual abuse, severe conflict or the child's absolute refusal.

Fixing the issue of child custody and visitation triggers the issue of child support. In many cases, the issue of child custody includes visitation, and the child support order is a subsequent order, which emanates from the former. The types of child custody and nature and forms of visitations have direct bearings on child support, otherwise called maintenance.

\subsection{Maintenance}

Child support is the most common support awarded upon divorce. ${ }^{97}$ When courts order one parent to have primary physical custody of the child, the other

${ }^{90}$ Id., p. 310.

${ }^{91}$ Dwyer, supra note 74, p. 47.

${ }^{9}$ Stark, supra note 6, p. 161.

${ }^{9}$ Id., p. 171.

94 Ibid.

${ }^{95}$ Ibid.

${ }^{96}$ Ibid.

97 Thomas F. Burrage and Sandra Morgan Little (2003), Divorce and Domestic Relations Litigation: Financial Adviser's Guide, John Wiley \& Sons Publisher, New Jersey, p. 161. 
parent will typically have visitation right. ${ }^{98}$ The parent with less custody time is usually ordered to pay child support to the custodial parent. The support obligation of each parent may be determined on the basis of the percentage of time the child spends with each parent. ${ }^{99}$ Child support is another important indicator of non-custodial involvement in post-divorce parenting activities. ${ }^{100} \mathrm{It}$ is assumed that the custodial parent is meeting his/her child support obligation through the custody itself. ${ }^{101}$ Therefore, fixing child custody and visitation rights also involves determining who is required to supply child maintenance and how much? Child support is simply an amount of money that divorce courts order one parent to pay to the other regularly, usually monthly, until a child attains majority. ${ }^{102}$ Payments are often made to the parent with whom the child lives. ${ }^{103}$

"State laws differ, however, with respect to the amount of support to be paid, the process through which this amount is determined, the duration of support", the mechanisms for its enforcement and collection. ${ }^{104}$ In some states (for instance Japan), parents agree on child support. ${ }^{105}$ "If they are unable to do so by themselves, they must go to mediation, where a trained third party will help them resolve the matter". ${ }^{106}$ Other States leave child support determination to the discretion of the court while ordering the court to take into account the following factors: the amount of the financial need of the child, the financial resources of the noncustodial and custodial parents, respectively, and the standard of living the child would have enjoyed had the parents remained married. ${ }^{107}$ "The lack of specific guidelines often produces unpredictable and widely ranging results, which in turn makes it difficult to negotiate support. The custodial parent usually incurs a disproportionate share of responsibility because s/he is actually meeting the child's expenses on a day-to-day basis”. ${ }^{108}$

${ }^{98}$ Dwyer, supra note 74, p 47.

${ }^{99}$ Woodhouse, supra note 23, p. 355.

100 Cheryl Buehler \& Jean M Gerard (1995), "Divorce Law in the United States: A Focus on Child Custody”, Family Relations, Vol. 44, No. 4, Helping Contemporary Families, pp. 439-458, p. 443.

${ }^{101}$ Woodhouse, supra note 23, p. 355.

102 Roderic Duncan (2007), A Judge's Guide to Divorce: Uncommon Advice from the Bench, Consolidated Printers, USA, p. 160.

103 Ibid

${ }^{104}$ Stark, supra note 6, p. 206.

105 Ibid.

106 Ibid.

107 Ibid.

108 Ibid. 
The mechanisms for determining the amount of child support vary considerably among states. ${ }^{109}$ They include a percentage of the obligor's income, which sets a flat or varying percentage based solely on the noncustodial income. ${ }^{110}$ This model assumes that the noncustodial parent will contribute what $\mathrm{s} /$ he can. Another model is based on the parents' combined income. ${ }^{111}$ This assumes that child support should represent the same proportion of parental income a child would receive if the parents lived together. A third model begins by assuring the ability of the noncustodial parent to meet the child's subsistence needs. Thus, only when the noncustodial parent's income exceeds a certain minimal amount is any obligation imposed. ${ }^{112}$

Despite these differences, computation of child support is normally based on the respective income of the parents, the amount of time the children spend with each parent, and any extra or extraordinary expenses each parent may incur. ${ }^{113}$ These extraordinary expenses may be for childcare, medical expense, school tuition, or other special needs of the children. ${ }^{114}$ Regardless of the model adopted by a court, income determination is a prerequisite to the computation of child support. The court first determines the appropriate incomes of the parents that are available for purposes of child support computations and this involves deciding whether certain types of income should (should not) be included in the determination of child support. ${ }^{115}$

If there are changing circumstances such as change in income level, the time a child spends with a parent, or change in the special needs of a child, courts may revise the original child support payments. ${ }^{116}$ An unanticipated increase in health care needs, for example, may also justify a modification. ${ }^{117}$

\section{The Legal Regime and Practices of SNNPR Courts on Child Custody}

Children are cared for and supported by their family whether they were born in wedlock or out of wedlock. ${ }^{118}$ Both parents have a legal duty to support their

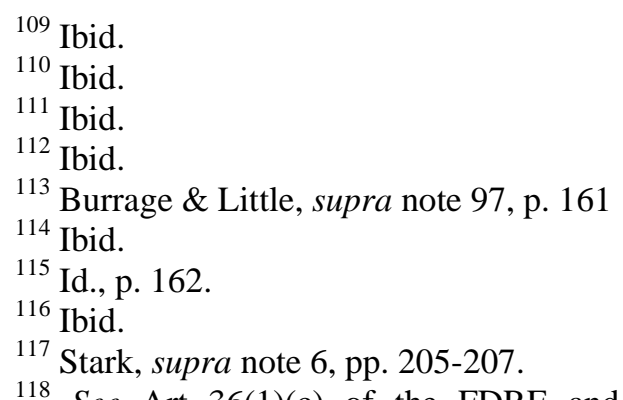

118 See Art 36(1)(c) of the FDRE and SNNP regional state Constitutions. The Convention on the Right of the Child also requires state parties to use the principle of 
child according to their ability irrespective of their marital status: married or separated. ${ }^{119}$ When the spouses decide to divorce, they have two options: either they decide by agreement regarding the tutor and guardians of their children or let the court decide it for them. ${ }^{120}$ In the latter case, courts are expected to take into account the best interest of the child as their primary consideration. ${ }^{121}$ The principle of best interest of the child is applicable for all decisions regarding children, be it custody, visitation right or maintenance.

Child custody decision is an announcement or prescription of the future part each parent will play in the child's life over the years of her/ his childhood. ${ }^{122}$ Ethiopia's revised family law allows courts (that decide the dissolution of marriage) to determine which spouse shall have custody of the children, health, maintenance, and the rights of parents and children to visit each other. ${ }^{123}$

'the best interests of the child' as their primary consideration in all actions that concern children. The provision of the Convention reads: "In all actions concerning children, whether undertaken by public or private social welfare institutions, courts of law, administrative authorities or legislative bodies, the best interests of the child shall be a primary consideration." (See Article 3 of the Convention on the Rights of the Child, Adopted and opened for signature, ratification and accession by General Assembly Resolution 44/25 of 20 November 1989 entry into force 2 September 1990).

${ }^{119}$ See 36(1) (c) of the FDRE and the SNNP regional State Constitutions cum with Articles 234 \& 236 of the SNNP regional state family code.

${ }^{120}$ See Art 221 of the Revised Family Code and Art 236 of the SNNPR state family code.

${ }^{121}$ See art 36 (2) of the FDRE Constitution.

122 Elizabeth S. Scott (1992), "Pluralism, Parental Preference, and Child Custody”, California Law Review, Vol. 80, No. 3, pp. 615-672, p. 617. $<$ http://www.jstor.org/stable/3480710 > (Accessed: 24-08-2016).

${ }^{123}$ See article 128 of the SNNP regional state family Code. There are persons who claim that courts should see child custody, visitation and maintenance cases in absence of divorce claim. However, there are several family code provisions that support reluctance of the courts to see child custody case in absence of divorce claim. In the first place, parents are the joint custodians of their minor child. This can be inferred from the provision of the Family Code which provides "The father and the mother are, during their marriage, jointly guardians and tutors of their minor children.” (See Article 219 and 234 of the RFC and the SNNP regional Family code respectively). The family code also indicates that "The spouses shall have equal rights in the management of the family". However, "In case of death, disability, unworthiness or removal of one of the parents, the one who remains shall alone exercise such functions.” (See article 220 and 235 of the RFC and the SNNP regional Family Code respectively). The court would assign guardian and tutor for the child. A minor shall be placed under the authority of a guardian for proper care of his person and tutor for 
Spouses are authorized to resolve the issues of custody and visitation privately through negotiation. ${ }^{124}$ However, if they cannot reach an agreement on their own, the only alternative they have is to wait for the court decision.

The court is expected to examine the satisfaction of the best interest of the child based on various parameters such as income, age, health, and condition of living of the spouses. From the children's perspective the court is expected to pay attention to the age and interests of the child. ${ }^{125}$ The Cassation Bench of the Federal Supreme Court has considered two factors that should be considered in the determination of child custody. These are the best interest of the child (which conventionally focuses on spousal status quo and financial strength coupled with the age of the child) and the right of child to be heard of his/her interest, (otherwise called "the will of the child") whether s/he likes to remain with her/his mother or father. ${ }^{126}$

As highlighted in the preceding sections, the concept of child custody contains two major components: legal and physical custody. However, such kind of classification is found neither in the Federal revised family law nor the SNNP regional state family code. The law only requires a court (that decides the dissolution of marriage) to decide child custody. ${ }^{127}$ The fact that the law is open in this regard, coupled with the existence of various types of child custody that involve the combinations of legal and physical responsibilities leaves a very wide room of discretion to courts in deciding child custody disputes.

Despite this discretion, which emanates from the law being open, in practice, courts do not distinguish between physical and legal custody. Out of the cases collected from different courts, in $98 \%$ of the cases, courts give child custody to either of the parents. ${ }^{128}$ By implication, legal and physical custody of the child

his pecuniary interests and the administration of his property. (See Articles 216 and 231 of the RFC and the SNNP Regional Family Code respectively).

${ }^{124}$ Id., 236 (1).

125 Id., 128(2).

${ }^{126}$ Cassation file number 35710, Vol. 8, p. 243.

127 See article 236(2) of the SNNP Regional State Family Code.

128 See File No. 03550; the applicant W/ro Yewubidar Tsegaye vs. Ato Tekalign Abebe (respondent) had a child whose age is one year and eight months. The applicant petitioned to court claiming child custody. The respondent also claimed the same. The court rendered child custody solely for the mother. Likewise, the court rendered a similar decision (i.e., child custody to the mother alone) in File no. 02505, i.e., W/ro Abebech Asefa vs. Ato Mesfine Sileshi; W/ro Amsalech Abebe, the court rendered custody for the mother only (File number 02594); and W/ro Sintayehu moges vs. Ato Alem Tsegaye (File number 03039). On the other hand, in the case between Ato Lukas Gualto vs. W/ro Misirach Tesfaye, the court rendered the custody of the child in favor of the applicant (File no. 3222). 
coincide and is placed on the same person. ${ }^{129}$ The other important point that is worth mentioning is the kind of legal custody the parents have over their minor child: joint (shared) or sole legal custody.

Unlike sole legal custody which gives one parent wider power to make decision regarding the child's upbringing and wellbeing, joint legal custody enables the parents to make joint decisions on all matters having a significant impact on their children's lives. The Revised Family Code is imprecise whether courts can give sole or joint child custody. However, the practices, based on the cases, reviewed during this research show that courts give sole child custody for either of the parents. In such cases, one parent is named the custodial and guardian with whom the child will live and who usually has a whole range of rights. Such parent is allowed to make all the decisions about the child's life. By logical extension we may conclude that the custodial parent will have the right to make all major decisions regarding the child's health, welfare, education, and religious upbringing. This situation remains unchanged unless the spouses reverse (of course with the approval of the court) such child custody arrangements by agreement.

In one court proceeding, ${ }^{130}$ the applicant filed an application, principally seeking divorce coupled with liquidation of property, which also involved child custody. The respondent, on his part, also sought child custody. The respondent, during oral arguments, sought sole child custody -which includes both legal and physical custody- and submitted an alternative claim to be given a right to involve in some major decisions regarding the child's life, which includes discharging of school fee, providing transportation services and tutoring the child. The court, looking at the enthusiasm of the respondent to have a role in the life of the child, asked the applicant whether she agrees with the proposal of the respondent. Based on her consent, the court accepted and approved the proposal of the respondent, which has some elements of joint custody. Here one may question the legal base of the decision under Ethiopian law. Although the law simply states the judicial power to decide over the divorce and custody, this allows courts to apply any doctrine or alternative notions that they think yield a better outcome. Hence, the decision of the court is in conformity with the law.

As highlighted earlier, physical custody gives the parent rights to physical control over the child and for the daily care of the child. ${ }^{131}$ It relates to physical

129 Ibid.

${ }^{130}$ The case was decided at Hawassa first instance court, family bench, in October/ November 2016.

${ }^{131}$ Clarke-Stewart and Brentano, supra note 22, v. 176. 
placement and the amount of time children spend with each of the parents. ${ }^{132}$ The Federal Revised Family Code and the SNPPR Family Code do not indicate the type/s of physical custody (shared, sole, or split) adopted by the law. The law seems to refrain from creating a general presumption for joint custody, but it grants discretion to courts, including the decision to allow sole custody.

Parents can agree on the terms of the custody arrangement. If the court finds their agreement in the best interest of the child, it approves their agreement. Where the spouses cannot agree on who should have physical custody, the court will grant it either solely to either of parents or allow joint physical custody to both of them. The law does not indicate the conditions which warrant the choice of one kind of physical custody over the other. It also fails to set down the circumstances under which a court is expected to grant sole, joint or split custody. Sole physical custody seems to be the most prevalent custodial arrangement in Ethiopia. ${ }^{133}$ In 90\% of the court cases in SNNPR examined by this author, courts rendered sole child custody for one of the parents, predominantly favoring the mother. ${ }^{134}$

The Federal Revised Family Code and the SNNPR Family Code envisage the possibility of revision, and empower the court, on application and taking into account the change of circumstances, to revise or reverse its custody decision. Either parent can apply at any time for a review of the child custody decision so long as the applicant shows the existence of change of circumstances. A parent must prove to the satisfaction of the court the extent to which the revision is likely to improve the quality of life for the child. Grounds for such revision could be the existence of a better school system, or a better climate that will

${ }^{132}$ Lawrence M. Berger and other (2008), “The Stability of Child Physical Placements Following Divorce: Descriptive Evidence from Wisconsin”, Journal of Marriage and Family, Vol. 70, No. 2, pp. 273-283, p 273.

133 See case cited, supra note 128. However, in Ato Talemis Degaga vs. W/ro Rahiel Tadesse, the court rendered child custody for both parents. The parties to the case have four children. The case was instituted by the applicant, Ato Talemis Degaga, seeking custody of their four children. The court assigned a social worker to study the best place for the child to reside. The court, after examining the investigation and recommendations of the social worker decided that three of the children should live with their father and one with the mother. (File No. 30689).

${ }^{134}$ See cases cited, supra note 128. In ten percent (10\%) of the reviewed cases, the court rendered child custody for the father. In Ato Lukas Gualto vs. W/ro Misirach Tesfaye (File no. 3222), the litigants have a child, 2 years and 8 momths old. The applicant, Ato Lukas Gualto, petitioned to court seeking child custody. The respondent, W/ro Misirach Tesfaye, challenged his claim. Finally, the court rendered the custody of the child in favour of the applicant. On can also find similar decision in the case between Ato Talemis Dgaga vs. W/ro Rahiel Tadesse and Ato Meseret Mengesh vs. W/ro Felek Magujie (File No. 30689 and 30799 respectively). 
benefit the child's health. The child may be indirectly advantaged where the custodial parent's standard of living is raised, thereby raising the child's standard of living, due to a new job or the remarriage of the custodial parent.

If the court gives exclusive child custody to one parent, the noncustodial parent will have visitation rights as agreed by the spouses or ordered by court. For instance, in sole custody, the noncustodial parent is usually awarded visitation rights and may also have the authority to make routine or emergency decisions while the child is in his/her temporary care.

\section{Ethiopian Law and Overview of Some Judicial Decisions on Visitation}

As highlighted earlier, the right of visitation, or access of noncustodial parents to a child, is favored in many countries. ${ }^{135}$ This is with the assumption, that when the child has direct contact with the noncustodial parent on a regular basis, the noncustodial parent is likely to contribute much to the child's life and strength. ${ }^{136}$ Besides, parents have a fundamental right to spend time with a child after divorce. ${ }^{137}$ If one parent has sole physical custody, the other parent will have visitation rights. ${ }^{138}$ The arrangements for contact can define the potential of relationships between child and parents during and immediately after parental separation. Courts are expected to determine the types of visitations or frequencies of access of noncustodial parents to a child. Such arrangements are among the most difficult aspects of the whole process of separation and divorce.

The right of visitation or access of noncustodial parents to a child is embodied under Ethiopian law. ${ }^{139}$ Courts shall grant reasonable visitation rights to a parent unless it is shown that it would be detrimental to the best interest of the child, a factor which should by taken by courts as primary consideration. ${ }^{140}$ However, there can be difficulties in establishing workable arrangements that satisfy all parties. ${ }^{141}$ In particular, the right of visitation may be compromised by the principle that protects the will or consent of the child. ${ }^{142}$ In this regard, the SNNP Regional Family Code allows divorcing spouses to either resolve their issues by agreement or (if they fail to do so), submit the case to court that

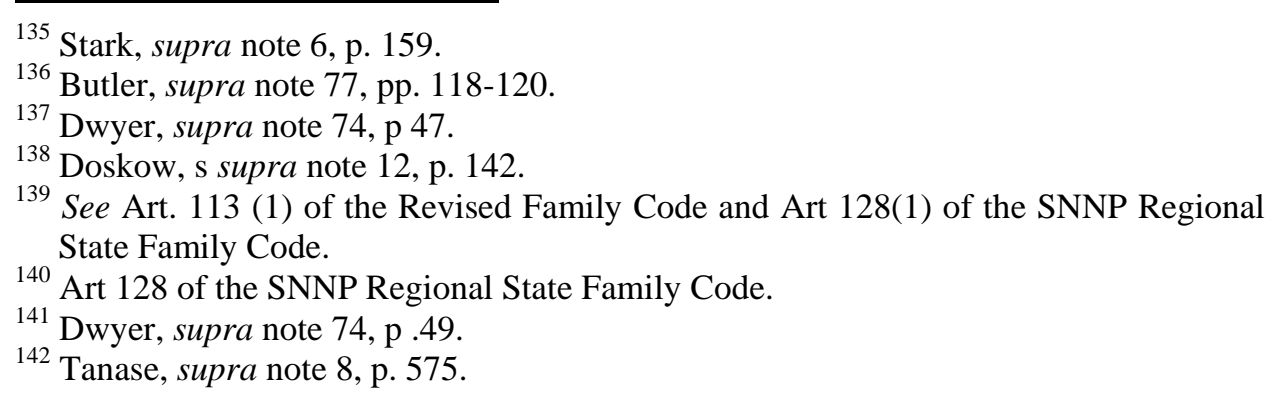


determines child custody and visitation. ${ }^{143}$ In this regard, the SNNP Regional State Family Code provides:

"Where the spouses decide to divorce by mutual consent in accordance with Article 86 of this Code, they shall decide by agreement regarding the tutor and guardians of their children. Where, in any case of divorce, the spouses did not agree on the tutorial and guardianship of their children, the court which decides the divorce shall also decide the tutor and guardian of children." 144 "The court shall, upon deciding the dissolution of marriage, also decide as to which spouse shall have custody of the children .... and the rights of the parents and the children to visit each other". ${ }^{145}$

The court shall, when deciding child custody, also decide the nature and frequency of contact that children have with both parents. This shows that courts shall grant reasonable visitation rights to a parent unless it is shown that the visitation would be detrimental to the best interest of the child. This is because "visitation is intended to help the healthy development and character-building of the child, and must be appropriately limited in scope and manner to meet those ends." 146

However, the family law is silent on whether the type of visitation that it adopts is standard, supervised or virtual. Yet, there are legal principles that guide courts in their decisions of visitation: (a) their decisions must be in the best interests of children; and (b) courts must give effect to the legal rights of non-custodial parents to form or maintain relationships with children thereby allowing them to be involved in the child's life. This means visitation rights may be standard, virtual or supervised in Ethiopian context as well.

Ethiopian courts have very wide discretion in deciding visitation disputes. In most of the cases, courts maintain the right of a noncustodial parent to visit his/her child. However, there are variations in their decisions. In some of the cases the court specifies duration and form of visitation. ${ }^{147}$ In such cases, the

143 See Art 221 of the Revised Family Code and Art 236 of the SNNP Regional State Family Code.

${ }^{144}$ Art 236 of the SNNP Regional State Family Code. Art 221 of the Revised Family Code embodies similar content.

145 Id., Art. 128.

146 Tanase, supra note 8, p.571.

147 See file number 06334 W/ro Belayinesh Wolans vs. Ato Dereji Biruk. The applicant requested child custody for her two children whose ages were two and four. The respondent agreed with W/ro Belayinesh's proposal. Hence, the court rendered child custody for the mother and maintained the respondent's right to visitation during the weekends, on Saturday and Sunday. However, the time and the place of visitation are not mentioned in the decision. Similarly, in the case between W/ro Meseret Yemane vs. Ato Faries Mintieto, the court rendered child custody for the mother. The 
court decides how much contact a non-custodial parent should have with a child. It provides for the noncustodial parent to visit the child on the weekends. In this situation, the non-custodial parent has two possibilities: either to visit the child at the place where the child resides or to take the child during the weekends (after school on Friday) and bring to the custodial parent on Sunday. Such kind of decision would help children to have frequent, meaningful and continuing contact with each parent thereby enhancing the healthy development of children.

In many cases, the court merely mentions the right of the noncustodial parent to visit his/her child without specifying how and when. ${ }^{148}$ It is not clear whether this involves staying at the non-custodial parent's house, overnight visitation, or daytime visits. In such decisions, how much contact a non-custodial parent has is vague, and a non-custodial parent may overstretch the visitation to include overnight visits which may also involve extended days.

There are also cases where courts overlook the issue of visitation. ${ }^{149}$ They fail to specify the kind of visitation the noncustodial parent has over his/her child, thereby adversely affecting the regularity and predictability of the noncustodial parent's visitation schedule. Under such circumstances it becomes difficult to interpret the scope and features of visitation. Visitation could be supervised if contact of the child with the parent places the child in serious

applicant and the respondent have two children whose ages were four and nine. Following the dissolution of their marriage, the applicant requested the custody of her two children, both in her statement of claim and during the oral argument. On the other hand, the respondent failed to raise this during the oral litigation. For this reason, the court awarded child custody for the applicant and visitation right for the respondent on Saturdays and Sundays (File No 05399). In (File No. 03039) W/ro Sintayehu Moges vs. Ato Alem Tsegaye, the court authorized the respondent to take the child on Fridays after school and bring the child back to the applicant on Sundays.

${ }^{148}$ See File No. 02594 (W/ro Amsalech Abebe vs. Ato Hojela Tsegaye), File No 02505 (W/ro Abebech Asefa vs. Ato Mesfine Sileshi), and (File 01054) W/ro Rahiel Hayilu vs. Ato Hintsa Tekilu. In all of these cases, the courts maintained the right of visitation for noncustodial parent without indicating the duration of the visitation, its form and place of visitation.

${ }^{149}$ In File No. 01054 (W/ro Rahiel Hailu vs. Ato Hintsa Teklu), the parties in dispute have one child aged seven years. The child was with the mother during the divorce process. Following the dissolution of the marriage, none of the parents raised the issue of child custody. As a result, the court (at its own initiative) awarded child custody to the mother. The consent of the child was not heard. The court that rendered child custody did not also address the issue of the noncustodial parent's visitation right. In W/ro Workayantsifu Atsinafu vs. Ato H/Micheal Belachew (File No. 02250), as well, the court awarded custody for the applicant without specifying the visitation right of the respondent. 
physical, emotional, or moral danger. It may also be blocked if the visitation poses a threat to the safety, or physical or mental health of a child. Under such cases, courts require visitation to be made in a specified 'safe' place or in the presence of a neutral third party, which enables the noncustodial parent to maintain a relationship with the child while assuring the child's security. The pace in the development of supervised visitation is yet to be seen in Ethiopia.

The law does not indicate the condition in which the non-custodial parent can be deprived of access to the child. Moreover, the law does not clearly address the contents of the right to visitation. For instance, if the parent with legal custody has decided to raise the child in a certain faith, can the noncustodial parent with visitation rights take the child to another religious faith? Here again, neither the practices of the courts nor the reviewed cases offer insights to this issue. However, it can, as stated earlier, be argued that if a custodial parent decides to raise the child in a certain faith, the noncustodial parent with visitation rights may not take the child to another faith. ${ }^{150}$ By implication, visitation does not annul the long-range decisions of the parent with legal custody. The noncustodial parent will only have the authority to make routine or emergency decisions while the child is in his temporary care.

Upon application, a court can take into account the change of circumstances, and revise or reverse its visitation decision. Restructuring visitation may involve rescheduling visitation for more time during the summer and over school holidays, but such rescheduling can involve less frequent intervals of time.

\section{Ethiopian Law and Overview of Some Judicial Decisions on Maintenance}

\subsection{Overview of the law on child support}

As Me Rodgers duly states, "the obligation to support a child is not dependent upon the marital status of the parent, but purely upon the status of being a parent" ${ }^{151}$ Parents are responsible to give their children all the necessary care and support until they become legal adults. ${ }^{152}$ Also, children are entitled to a decent standard of living. ${ }^{153}$ Hence, the parent with less custody time is usually ordered to pay child support to the custodial parent. ${ }^{154}$ This stems from the argument that "One of the definable aspects of parental responsibility is the

\footnotetext{
${ }^{150}$ DeSimone, supra note 9, p. 51.

${ }^{151}$ Me Rodgers (2004), Understanding Family Law, Cavendish limited Publisher, Great Britain, p. 107

${ }^{152}$ Doskow, supra note 12, p. 145.

153 Stark, supra note 6, p. 206.

${ }^{154}$ Woodhouse, supra note 23, p. 355.
} 
obligation to support a child financially”. ${ }^{155}$ This begs the argument that there should be a guideline, which embodies provisions on the assessment, collection and enforcement of periodical maintenance payable by certain parents with respect to children who are not in their care.

In Ethiopia, the law sets forth the existence of child support obligation on parents. ${ }^{156}$ However, it fails to answer a number of issues such as the amount of support to be paid, the process through which this amount is determined, the duration of support, and the mechanisms for its enforcement and collection. Besides, the law remains silent with respect to some essential issues that are important to determine the amount of child support, such as the ratio of each parent's contribution against their combined incomes, the percentage of time the child spends with each parent and its implication in child support payment, and who pays necessary expenses if the child needs intensive care.

The law does not give a clear definition of income. As the calculation depends on the income of parents, it is going to be hard to get child support if they have no income. Deciding these matters is very important, given the fact that the amount of child support payable is directly related to these issues. ${ }^{157}$ "The lack of specific guidelines often produces unpredictable and widely ranging results, which in turn make it difficult to negotiate support. The

${ }^{155}$ Frances Burton (2003), Family Law, Cavendish Publisher, United States of America, p. 235.

156 See, Art 113 of the Revised Family Code and 128 of the SNNP Regional State Family Code.

${ }^{157}$ Since 1990, Ethiopia has Draft Child Support Guidelines, which provide a formula for calculating child support based on a proportion of each parent's gross income. When parents are divorced or if they cease to live together with their children as a family, courts are required to establish the amount of child support that should be paid by a noncustodial parent. The Draft Guidelines allow courts to vary the rate of maintenance payable depending on the place where the child support application is made. The situations in which this is permissible are set out in Schedule B of the drat guideline. The Draft Guidelines establish the method for calculating child support under different contexts. Some the courts use this guideline to calculate child support. This guideline is designed to ensure consistency and predictability in the amount of child support. However, the Draft Guidelines are not implemented in most courts. The Draft Guidelines recognize to differences in child support levels by custody type. In this regard, the factors that are considered include the number of overnights per year the child is supposed to spend with the noncustodial parent as specified by the court or agreement, the income of the noncustodial parent and of the recipient parent, the place where the child lives, and the number of children for whom noncustodial is obligated to support. 
custodial parent usually incurs a disproportionate share of responsibility because she must actually meet the child's expenses on a day-to-day basis.”"158

As with many other issues in divorce, both spouses can simply agree on the amount of monthly child support payments. ${ }^{159}$ At times when spouses decide to divorce, they are given the chance to resolve issues relating to maintenance privately. A court will usually accept and enforce that agreement unless the amount is well below what the best interest of the child requires. On the other hand, if they cannot reach an agreement on their own or through the help of a neutral third party, the last option is letting courts to intervene in the matter. Here again, courts are given one test to apply, i.e., they should consider what is best for child since maintenance merely continues the support which the child was entitled to receive while the marriage existed. ${ }^{160}$

Under the FDRE and the SNNP Regional State Constitutions, both parents have equal rights and duties to take care of their children and to raise them. ${ }^{161}$ Such parental obligation will remain unchanged whether the parents are married or divorced. In case of divorce, the courts that decide over the divorce are equally obliged to determine the rights and obligations of each parent towards their children. Once custody of the children has been decided, courts are required to render decision regarding the amount and the method of calculation of child support payment, which will be paid to the custodial parent.

\subsection{Overview of some SNNP regional court decisions}

Parents shall contribute to child support in proportion to their respective means of income, otherwise called the ratio of each parent's income to their combined incomes. ${ }^{162}$ However, there are variations in several decisions of courts. From the reviewed forty SNNP regional court decision, in 38\% of the cases, the courts determined the amount of child support without revealing the respective incomes of the parents. ${ }^{163}$ In $12 \%$ of cases, the courts determined the amount of

158 Stark, supra note 6, p. 206.

159 Article 236(1) of the SNNP Regional State Family Code.

${ }^{160}$ See Article 36(2) of the FDRE and SNNP Regional State Constitutions along with Article 123(1) \&(2) of the SNNP Regional State Family Code.

${ }^{161}$ See Article 36(1) (c) of the FDRE and SNNP Regional State Constitutions.

162 This can be justifiably inferred from the argument that parents have equal rights and duties to take care of their children and to raise them.

163 See (File No. 00693) W/ro Marta Densamo vs. Ato Kedir Aman in which the applicant W/ro Marta Densamo sought child support for her eight year-old child. The respondent had no objection on the maintenance request, and the court awarded ETB 100 (One Hundred Birr) per month. The court might have increase the amount of child support had it examined the level of the respondent's income. In (File No. 0478) W/ro Sintayehu Getahun vs. Ato Alemayehu webe, the applicant (W/ro Sintayehu Getahun) filed a petition seeking child custody and maintenance for her 
child support by focusing on the income of the noncustodial parent. ${ }^{164}$ In few cases (8\%), the courts passed over the child support claims. ${ }^{165}$ In one of these cases, the court argued that it left out child support claims affirming both parents had insufficient money to pay child support, to the other parent. In the remaining cases, which constitute $42 \%$ of the cases, the courts considered the combined incomes of the spouses. ${ }^{166}$ This finding shows that the courts incline

two children whose ages are not mentioned in the case. The respondent had no objection against these claims. The court awarded sole custody for the applicant along with monthly child support of Birr 400. It is not clear from the case how the court assessed the amount. The combined income of the parents was not also mentioned in the file. There are many cases that show similar practices such as W/ro Firehiwot Nigusie vs. Ato Kebede Alemu (File No. 04558), and W/ro Tigist Haile vs. Ato Tesfahun Fenta (File No. 04433).

164 See File No. 30600 (W/ro Animut Tezera vs. Ato Bayu Zewudu) in which W/ro Animut Tezera requested custody and maintenance for her child aged one year and seven months. The respondent also claimed custody. The court awarded custody for the mother due to the age of the child. The court extended its decision and ordered the respondent to pay maintenance. The court used the income of the respondent (which was Birr 10,014) as the basis for determining the amount of maintenance. The court awarded 1000 Birr as the amount of maintenance. A similar reference to the income of respondent is also made in W/ro Marita Tesfaye vs. Ato Mulatu Telet (File no. 31112) whereby the respondent's monthly income of Birr Eight Hundred was taken into account in the calculating the amount of child support.

${ }^{165}$ In Ato Meseret Mengesh vs. W/ro Felek Magujie (File No. 30799 the applicant, Ato Meseret Mengesh, requested child custody and child support. The applicant stated that the respondent has no permanent residence and adequate income. The respondent also counter-claimed custody and maintenance. Based on the recommendation of the social worker who was assigned to examine the contexts, the court allowed child custody for the applicant, and did not render decision on the issue of maintenance. The same holds true in the case between W/ro Amarech Bonga vs. Ato Ashenafi Loha (File No. 05735).

${ }^{166}$ In W/ro Mintiwab Tola vs. Ato Tesfaye Alemu (File No. 05148), the court examined the combined income of the parents in the calculation of child support for their child, aged nine. Similarly, in Ato Tsegay Tamiru vs. W/ro Tsehay Tesfaye, the court used the combined income of the parents who sought the custody of their twin children who were five years old. Both sought child custody, and the respondent in addition claimed child support. Custody was given to the respondent in addition to which the applicant was ordered to pay a monthly child support of Birr 1,200 (i.e. Birr 600 per child) out of his Birr 3,500-4,000 monthly income because the respondent was found to have no income. In W/ro Amsalech Abebe vs.Ato Hojela (File No. 02433), the court required both parties to declare their income (Birr 1,700 and Birr 1,980 per month respectively), and it considered the sum of their income to determine the amount maintenance. A similar method of reference to combined income was also used in W/ro Mebrat Qolicha vs. Ato Tamirat Mana (File No. 31090). 
towards applying combined incomes of the parents to an increasing number of post-divorce disputes.

The other point that needs to be noted is the issue of gross and net income dichotomy which courts use as a base to determine child support. As the amount of child support is, inter alia, determined based on the net income of the parents, the amount of money which is going to be considered for child support payment shall be determined after making usual deductions from the gross income, such as taxes, pension contribution, health insurance payment and so on. When we see the practices of courts in this regard, in $27 \%$ of the forty cases that were reviewed, the courts depended on income of the parents (after making necessary deductions) to determine the amount of child support, ${ }^{167}$ while in the rest of the cases (73\%), they simply took the gross income, mentioned either on the contract of employment or the income declared by the respondent. ${ }^{168}$

Asserting incomes of parents could be difficult if they have earned income from several sources. It can be argued that child support is determined after looking at the different sources of income of the parents that make up the total income. For instance, a person, in addition to employment income, may generate money from self-employment, farming and business activities. In this case, the courts regularly ask parents to provide the necessary income information.

However, there are circumstances in which parents may not provide necessary income information, or one of the parents may contest the income information provided to the court by the other parent. In these situations, courts are supposed to check other sources of information (from a third party) that shows income of the noncustodial parent. In the case of the self-employed noncustodial parent, the court may take annual or daily incomes of a third party that is engaged in the same economic activity and has the same level of financial position as a base in order to determine the income of the noncustodial parent.

On the other hand, if noncustodial parent is a businessperson, the court may request him/her to provide his/her financial information. This financial information might include copies of a person's taxation documents for the current year. However, if one of the parents contests the net income declared to the tax authorities or if the parents do not agree on the amount, the court will make further investigation and decide the amount. There is a case in which the respondent requested the court to calculate child support payment based on the amount assessed by the Customs and Revenue Authority. However, the applicant contested this amount, and the latter's contest was accepted by the court.

${ }^{167}$ Ibid.

168 See the cases highlighted above, supra note164 \& 165. 
Once the income of the parents, which will be used to calculate the child support is known, the next point is to set the amount a noncustodial parent should be ordered to pay. In this regard, there is argument that "the court may consider the standard of living the child would have had if the parents had remained together". ${ }^{169}$ "Child support refers to expenditures on behalf of a minor in order to meet the child's physical, mental, and emotional needs. This means, among other things, food, clothing, shelter, health care, recreation, and education". ${ }^{170}$ The amount for child support is intended to cover not only the direct costs for the children, but also the indirect costs, such as housing and transportation. Child support must also include special expenses such as special intensive care due to the health condition of the child. Baker argues:

The marginal expenditure measure requires that a child support obligor continues to contribute to the marginal support of the child as he would if he were sharing a home with the child and the other parent. The amount a person owes his or her child is determined by the standard of living the child would enjoy if the obligor were living with the residential parent and the residential parent was not living with somebody else. ${ }^{171}$

The applicant may ask "a court to determine what he would contribute if he were living and sharing resources with the mother and child."172 This requires looking at what parents in different income brackets generally spend on their children, the financial positions of both parents who are under litigation on the amount of child support, consistency in assessments, and a realistic sum which recognizes the true costs of child caring and rearing.

However, there are inconsistencies among the decisions of SNNP regional courts in this regard, owing to the absence of detail laws that regulate the assessment, collection and enforcement of periodical maintenance payable by noncustodial parents. In most of the cases, regardless of the income of the parents, child support in the form of maintenance did not exceed Five Hundred Birr (ETB 500) per child. ${ }^{173}$ In almost all of the SNNP regional court cases that

${ }^{169}$ Connell, supra note 65, p. 75.

${ }^{170}$ Id., p. 71.

171 Katharine K. Baker (2006), “Asymmetric Parenthood” in Robin Fretwell Wilson (ed.) Re-conceiving the Family: Critique on the American Law Institute's Principles of the Law of Family Dissolution, Cambridge university press, New York, pp. 121142, pp. $128-129$

172 Id., 129.

173 See the cases, supra note, 164 \&166. In Ato Adem Hamid vs, W/ro Hanae Abdulekedir, the Cassation Bench awarded Birr 12, 000 (Twelve Thousand) as child maintenance for the respondent, W/ro Hanae Abdulekedir. The applicant lodged his petition to the cassation bench against the decision of the lower courts concerning the amount of money awarded as child support. The first instance court took into 
were examined, there is lack of clarity on how the true costs of the childcare were assessed. Moreover, it is not clear whether the child support amount merely covers for food and clothing, or whether it also includes school fees.

Courts should not have been too stringent in deciding the amount of child support, because, this amount (same as the judicial decisions on custody and visitation) can be reviewed where there is/are new circumstance(s). The ground for such review can be factors such as change in jobs, loss of job due to lay off, and reduced income from self-employment. In spite of such prospects of review, however, child support payments are given priority over other expenses.

\section{Concluding Remarks}

Custody, visitation and the obligation to supply maintenance are core postdivorce issues that should be resolved in order to ensure children's wellbeing. Child custody involves physical control over a child and the legal authority to make decisions on medical, educational, health, and welfare needs of a child. Upon divorce, one of the parents becomes the custodial parent while the other noncustodial parent is entitled to visitation rights.

Visitation right defines the conditions for the noncustodial parent to have contact with the child or enables a child to maintain physical contact with the noncustodial parent on a regular basis. Courts are expected to determine the types, frequencies and forms of visitation which may be categorized as standard, supervised or virtual (based on the timing and the manner in which visitations are conducted). The determination of child custody and visitation triggers the issue of child support so that parent with less custody time pays his/her fair share of the childcare cost to the custodial parent. Child support is simply an amount of money that divorce courts order a noncustodial parent to periodically

account the strong financial position of the respondent, and ordered the applicant to pay Birr 50, 000 (fifty thousand) per month. This amount was reduce to Birr 12, 000 upon appeal to the Federal High Court. The applicant, Ato Adem Hamid, lodged his petition to the cassation bench. However, the Cassation Bench confirmed the decision of the Federal High Court stating that the amount of child maintenance is decided by taking into account the economic status of non-custodial parents and in accordance with local custom where the claimant resides. The cassation bench also indicated that the applicant has had substantially high income. The court noted that the amount of the child support should not be determined on the basis of the amount of child support an average Ethiopian would provide for his/her child. (See Cassation File No. 98552, Federal Supreme Court Cassation Division Case Reports, Vol. 16, pp. 173-176). The amount a person owes to his or her child is thus determined by the standard of living the child would have enjoyed had the child lived with his/her parents. 
and regularly (usually every month) pay the custodial parent, until a child attains legal adulthood.

Ethiopian law accordingly imposes duties on parents to provide care and support for their children irrespective of their marital status. Both the revised federal and SNNP regional state family laws provide that a court that decides the dissolution of marriage also renders decision on the custody, education, health, and maintenance of the children as well as on the rights of the parents and the children to visit each other. In this regard, courts apply the rule of best interest of the child. Although Ethiopian law embodies this general principle, the relevant family laws do not have detailed guidelines that regulate various issues, which pertain to child custody visitation and child support.

There are diverse types of child custody arrangements that involve various combinations of legal and physical responsibilities, which parents have over their children. Since our law is too general in this regard, the court decisions that are examined in this article do not distinguish between physical and legal custody, and in effect, legal and physical custody of the child usually rests on the same person.

With regard to the right of visitation or access of noncustodial parents to a child, the conventional and frequently applied visitation arrangement seems 'standard visitation'. In all the cases reviewed in this research, courts maintain the right of the noncustodial parent to visit his/her child. However, there are variations in court decisions. Although the courts specify the duration of visitation and its form in some cases, the details of visitation are not stated in many cases. There are also instances where courts utterly overlooked the issue of visitation.

The gaps in the law likewise relate to child support. Although Ethiopian law requires a noncustodial parent to provide child support, it fails to address a number of issues such as the amount of support to be paid, the procedure for determination of the amount, the duration of support, and the mechanisms for its enforcement. As a result, there are variations in several decisions of courts.

The inconsistencies observed in the decisions of courts and the gaps in predictability thus call for the sustained professional development of judges and pursuits to enhance the competence of the judicial sector in general. Moreover, there is the need for detailed laws that embody clear and adequate provisions regarding child custody, visitation rights, and maintenance. This would help ensure consistency and predictability in court decisions. 